\title{
The Industrial Electronics Learning Model Needs Analysis Based on Industrial Teaching at Vocational School
}

\author{
Purnamawati 1,*, Muhammad Yahya ${ }^{2}$, Sabran $^{3}$, A Arfandi ${ }^{4}$, Fitrah A. Darmawang ${ }^{5}$ \\ ${ }^{1}$ Department of Electronics Engineering Education, Universitas Negeri Makassar, Makassar, Indonesia \\ ${ }^{2}$ Department of Automotif Engineering Education, Universitas Negeri Makassar, Makassar, Indonesia \\ ${ }^{3}$ Department of Electronics Engineering Education, Universitas Negeri Makassar, Makassar, Indonesia \\ ${ }^{4}$ Department of Civil and Planning Engineering Education, Universitas Negeri Makassar, Makassar, Indonesia \\ ${ }^{5}$ Department of Electronics Engineering Education, Universitas Negeri Makassar, Makassar, Indonesia \\ *Corresponding author.Email: purnamawati@unm.ac.id
}

\begin{abstract}
This study aims to produce the needs analysis of the Teaching Industry-based on the Industrial Electronics learning model. This research type is development research which final product in the form of a Teaching Industry-based Industrial Electronics learning model. The research subject is Vocational School in Makassar City with the field of expertise in Industrial Electronics program and the Indicator competency achievement is Programmable Logic Controllers. Based on the needs analysis stage of the model, the results obtained are producing a Teaching Industrybased Industrial Electronics learning model by initial investigations of theoretically reviewing and analyzing the needs of Teaching Industry-based Industrial Electronics learning models, such as (1) The overview of teachers with the field of expertise industrial electronics in vocational schools, (2) Identification of Industrial Electronics learning objectives, (3) Problem Analysis of Industrial Electronics learning, and (4) Analysis of Teaching Industry Models.
\end{abstract}

Keywords: Needs analysis, learning model, industrial teaching, industrial electronics.

\section{INTRODUCTION}

The change of a nation is largely determined by the quality of its education. Education has an important role in achieving national development goals. The ongoing development in the era of globalization causes many changes in all fields. The needs and challenges of the increasingly complex world of work require that the workforce as human resources (HR) must be able to compete with the provision of professional competencies. Education is expected to be able to give birth to a generation of people who are strong, skilled, creative, innovative, imaginative, sensitive to local wisdom, and also technopreneurship [1].

Along with the growth of the world of work in Indonesia, the demand for skilled workers who graduated from Vocational High Schools (SMK) is increasing. Therefore, Vocational High Schools need to prepare and equip their students with knowledge and skills that are by the needs of the Business World and the Industrial World (DUDI). The development of Vocational High Schools is directed at increasing international competitiveness as a foundation in building the nation's independence and competitiveness in facing global competition [2]. The [3] has stated that the purpose of vocational education is to prepare for working life, the initial preparation of individuals for working life, the continuous development of individuals throughout their working life, and the provision of educational experiences for dealing with future job changes.

One of them is a competitive and skilled workforce born from quality vocational education that is relevant to the demands of the world of work that is constantly evolving. Thus, the world of education must also keep up with the changing times. Revitalization of vocational education needs to be carried out to prepare an additional 58 million workers with 21 st-century skills in the next 15 years to bring Indonesia to become a country with the world's number 7 economic power in 2030 [4].

The President has issued Presidential Instruction Number 9 of 2016 concerning the Revitalization of Vocational High Schools in the context of Improving the Quality and Competitiveness of Indonesian Human 
Resources which is the direction of future vocational education development. The Presidential Instruction explains that the Ministry of Education and Culture has the task of (1) making a roadmap for the development of Vocational High Schools; (2) perfecting and aligning the SMK curriculum with competencies according to the needs of graduate users ( link and match ); (3) increase the number and competence of educators and vocational education personnel; (4) increase cooperation with ministries/agencies, local governments, and DUDI; (5) improve access, certification of SMK graduates and accreditation of SMK; and (6) forming a working group for vocational development [5].

Taufiq Rizaldi (2015) explains that improving the quality of human resources needs to be directed at creating higher quality education graduates, improving workforce skills, and encouraging worker competency certification so that they can be competitive in ASEAN and international markets. Furthermore, Presidential Instruction No. 6 of 2014 concerning increasing national competitiveness in the context of facing the economic community. The Association of Southeast Asian Nations explains that workforce development, which focuses on: (1) Increasing Labor Competitiveness; and (2) Improving the competence and productivity of the workforce. These two things provide an understanding of the importance of developing quality human resources which is the main priority scale in producing a professional workforce to face the MEA.

In efforts to anticipate this statement, we need a learning model that can grow or improve thinking skills and work abilities. Vocational education institutions, especially SMK and DUDI, cooperate to build industrial classes with industry teaching so that the 21 st-century skills needed can be met in a synergy between SMK, DUDI, and government policies. Therefore, vocational education is basically "education for work". So it is very urgent to develop the "teaching industry" as a model to develop the skills of graduates skills, including the ability to use work equipment and critical thinking skills (critical thinking skills) in the face of the global workforce. Efforts to produce an effective model, it is necessary to analyze the needs of the learning model to be developed. Needs analysis is needed in assessing the initial phenomena needed in providing a clear picture of the Teaching Industry (IT) -based Industrial Electronics learning model (ELIND) as an alternative model that is effective in growing critical thinking skills and work skills of SMK students.

The IT learning model has the basic concept of transferring part of the educational process and industrial processes in a learning design so that competency-based education is held that gives birth to human resources who win in global competition [6]. IT learning is an industrial learning activity that aims to condition students into the actual production process situation in the industry, by presenting materials that are combined between SMK curriculum materials and materials from the industry so that synchronization occurs between the two materials. The [7] states that industrial teaching or industrial learning is a form of effort to provide a real experience to students by involving students in production/services in industry or schools by involving students directly. Industrial learning is certainly different from other learning, where industrial learning students gain real experience by industry needs.

Thus, to realize the conditions of IT learning requires the ability of teachers who are professional in their fields, and competent industrial instructors, innovative students can make new technological innovations. In addition, government policies that overshadow the ongoing process, so that the synergistic partnership of SMK, DUDI, and the government so that the fulfillment of graduates' abilities can be achieved according to the objectives of vocational education so that they can face various challenges in the 21 st century through the IT learning model. The research results of [8] found that the contribution of the implementation of entrepreneurshipbased teaching industry learning model to the improvement of productive skills competence had quite high criteria, the magnitude of the contribution of learning motivation to increasing the competence of productive skills of Boutique Clothing and Patisserie had high criteria and the magnitude of the contribution to the implementation of teaching industry model learning. based on entrepreneurship and learning motivation to increase the competence of productive skills have high criteria.

Critical Thinking Skills and work skills can be grown through the IT model, where critical thinking is an art in the process of analyzing and evaluating from a perspective to increase understanding. This requires a strong standard of thinking and deep attention [9],[10]. Critical thinking skills are also related to students' ability to analyze arguments, make conclusions using reasoning, assess or evaluate, and make decisions or problem solving [9], [11]. Meanwhile, workability can be seen as a balance between work demands and individual resources. Thus, this needs analysis is to answer the problems in designing IT models with systematic steps to grow both of them.

\section{METHOD}

This research is a qualitative descriptive study, which was conducted to obtain an overview of the data on needs analysis in developing the IT-based ELIND learning model. The results of the needs analysis are used as a reference or guide in producing the indicators of the IT- 
based ELIND learning model as outlined in the stages of the IT learning model and syntax.

This research was conducted in State Vocational High Schools, as the subject of the research was productive vocational high schools with ELIND expertise. The selection of research subjects was carried out in the following steps: (1) Selecting 2 (two) State Vocational High Schools in Makassar City at random as a place of research; (2) Choose a SMK that has an ELIND field; (3) Determining the object of research based on the selection of steps (1) and (2).

\section{RESULTS AND DISCUSSIONS}

\subsection{Results}

The results of the research are divided into 5 (five) parts, namely: (1) conducting a literature study of the development model, (2) a description of vocational teachers in the field of industrial electronics expertise in SMK, (3) the stages of development, (4) a description of the contents of the Electronic learning model. Industry, (5) Analysis of IT Models, and (6) Overview of FGD results on the design of the IT-based ELIND learning model.

\subsubsection{Conduct Initial Investigations Through A Literature Study of Development Models}

Initial activities were carried out in analyzing the needs of the model by conducting a literature study (supporting theories) in IT Model-based learning. This is very important to achieve learning objectives so that critical thinking skills and work skills can be realized as expected. The learning theories related to this module are the learning theories of behaviorism and constructivism, which are collaborated in learning the IT model. In addition, identification of IT-based industrial electronics learning steps was also carried out, and analyzing ITbased industrial electronics learning models. Furthermore, the design of IT-based industrial electronics learning models, IT-based industrial electronics learning concepts, IT learning principles, IT learning support components, and the positive impact of IT-based electronics learning on SMK graduates.

\subsubsection{Overview of ELIND's Vocational High School Teachers}

\subsubsection{Presentation of Male and Female Teachers}

The productive teachers of ELIND's skill competency in SMK who were involved and took a role in this study consisted of $56 \%$ male teachers and $44 \%$ female teachers. It can be concluded that most of the teachers in SMK are male because the interest in this field is still dominated by men, however, the motivation of female teachers to choose this field as a unique job and market opportunity is wide open. Male and female teachers in IT-based industrial electronics learning have a very big role in achieving learning objectives according to the lesson plans.

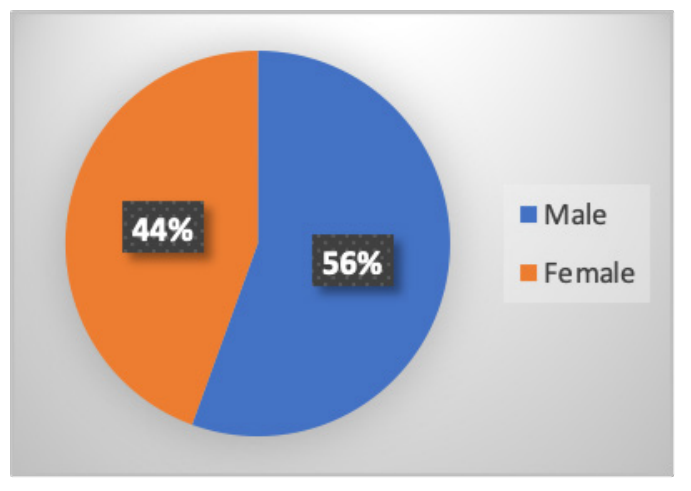

Figure 1 Presentation of Male and Female Teachers

\subsubsection{ELIND's Teacher Age}

Around $40.74 \%$ of ELIND's teachers of expertise are 50 years old, this shows that the teachers at the SMK have very adequate teaching experience in terms of age.

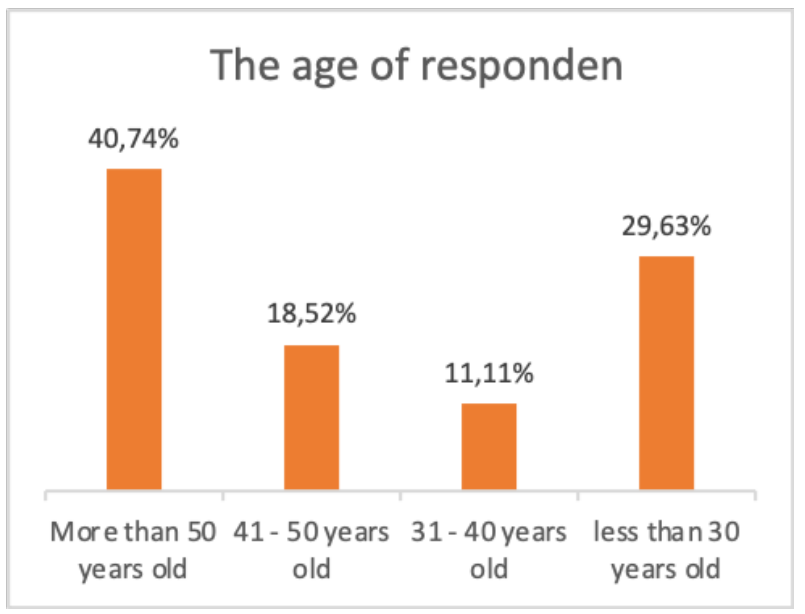

Figure 2 The age of ELIND's Teachers

\subsubsection{ELIND's Teacher of Working Period}

Theoretically, teachers who have a long working period have sufficient experience and competency skills. Based on observations and interviews, the data obtained for ELIND teachers' tenure of fewer than 10 years were $40.74 \%$, and $33.33 \%$ (21 to 30 years). These results describe that ELIND teachers, although the largest presentation has less than 10 years of teaching, these young teachers have adequate knowledge and skills, this is indicated by learning activities that involve active student interaction. 


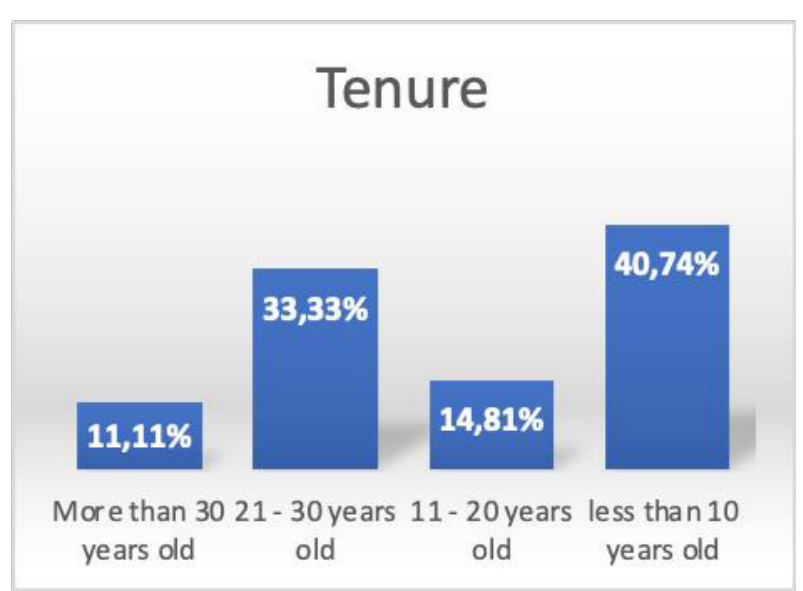

Figure 3 ELIND Teacher Tenure

\subsubsection{ELIND's Teacher Working Group}

As many as $37.04 \%$ of ELIND teachers have class $\mathrm{IVb}$, based on the monitoring of the teacher class level, it is a description of the level of expertise in ELIND's field of expertise in theory and practice. Teachers who do not yet have a class $44.44 \%$, teachers who do not have this class are contract teachers whose existence is very helpful for ASN (State Civil Apparatus) teachers in the school.

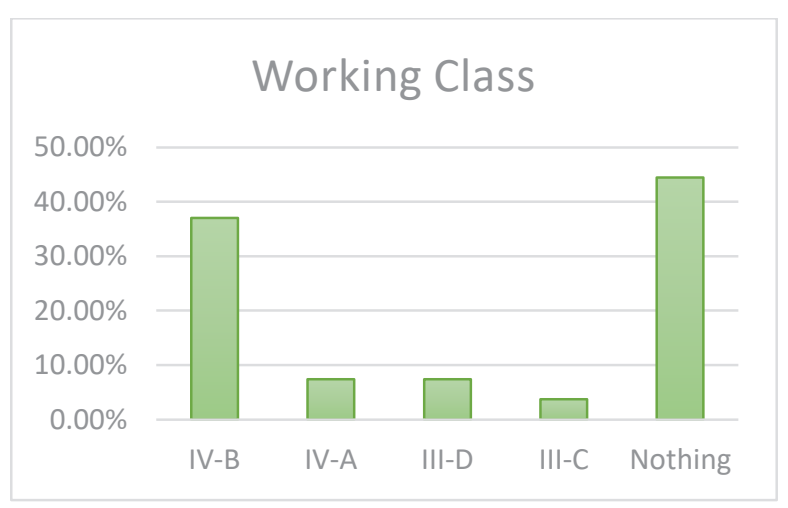

Figure 4 ELIND'S Teacher Working Group

\subsubsection{Stages of Model Development (Results of Preliminary Investigation)}

Initial investigation through needs analysis of learning model design in the ELIND field through observation activities at State Vocational Schools in Makassar City. The initial stage was interviews with the head of the ELIND Expertise Program, the Electronics Expertise Program, and several teachers in this area of expertise through face-to-face meetings. The data from the initial investigation obtain information that is used to draft the IT model.

\subsubsection{Identification of ELIND's Learning Objectives}

The learning objectives of Industrial Electronics Engineering Expertise Competence, namely educating students to have the ability/skills in the field of control systems and maintenance of industrial equipment based on electrical control, microprocessor, and PLC. Where the competencies above include general knowledge and skills of Electrical and Electronics, Microcontroller and Microprocessor, Pneumatic and PLC, as well as computer-based programming which is closely related to industrial production processes.

Industrial Electronics Engineering Expertise Competence is an expert program that specifically provides expertise for maintenance and repair, and (2) manufacture and assembly of household industrial electronics. In addition, students also gain expertise in instrumentation and control technology such as Programmable Logic Controller (PLC) and pneumatic electronics. Based on the results of observations and interviews with the Head of the Department and several teachers, the following information was obtained: (1) Graduates of Industrial Electronics Expertise Competence are expected to be able to carry out work as industrial electronics technicians, (2) can plan and organize the work of electronics technicians in the industry and other installations, (3) can program electronic automation systems with PLC and computers, plan, assemble, and install electronic devices for electronic automation systems.

The results of the interview explained that the competence of this field of work, students can master, namely: (1) Programming electronic automation systems with microprocessors, microcontrollers, PLCs, (2) Planning, assembling, installing electronic devices for electronic automation systems, and (3) All work-related with automation or control of industrial machines.

\subsubsection{ELIND's Learning Problem Analysis}

Industrial electronics competency learning has been carried out so far using a lecture and discussion learning approach accompanied by questions and answers. The learning approach is monotonous so that student motivation is not well developed. This learning condition causes critical thinking skills and work skills to not grow, even though this is needed to keep pace with the development of work equipment in the industry which is always updated. The practicum is carried out with improvised equipment, with simple techniques so that the learning objectives written in the Lesson Plan (RPP) are not fully realized properly. The production process using PLC as an important component of industrial work processes is not fully understood by students. Some of the special laboratory equipment in this area of expertise is 
not yet complete. ELIND equipment on PLC already exists but is still not complete so that the competencies expected in the RPP are not achieved optimally. This was discussed during the observation and interview process by providing input for the Head of Department and teachers. DUDI's partnership program to transfer knowledge and skills regarding this competence can be developed beyond the MoU which establishes bonds with each other by always being guided by the principles of mutual reinforcement, mutual benefit, and mutual trust. Through a partnership with DUDI, Vocational Schools can learn new technologies that have the potential to be developed into learning media, modules, or technological works, and the development of production units for Vocational High Schools.

The implementation of this partnership presents a real industry portrait presented in learning in Vocational High Schools (SMK) through the IT model. Students directly learn industrial concepts at school by building these concepts with industrial miniatures in them.

\subsubsection{Teaching Industry Model Analysis (IT Model)}

The learning-teaching industry is an industry of learning activities aimed at conditioning the learners into the actual situation of the production process in the industry, by providing the material that is combined between vocational curriculum materials with the material of the industry so that there is synchronization between the two materials. This IT model almost coincides with the teaching factory (TEFA), where the learning concept leads to work process-oriented learning in the industry. However, the difference is in the implementation of work process activities where the IT mode emphasizes industrial processes according to the competence of the field of expertise.

\subsubsection{Description of the Contents of The IT- Based ELIND Learning Model}

Phase 1 is the phase of receiving product orders and then identifying and analyzing order specifications. The teacher guides the students in discussing to identify and analyze the product specifications to be worked on. Then the teacher guides the students to write down the product specifications to be worked on. The next phase (Phase II) is the teacher making planning documents for order processing in the form of procedures, timelines, product designs, tools and materials, final specifications of orders. In Phase III, namely the provision of tools and materials to be used. In this phase, the teacher directs students to discuss methods of providing effective and efficient tools and materials. Next, direct students to provide tools and materials that will be used to work on the product.
Phase IV is the process of working on products where the teacher will direct students to discuss effective and efficient methods of working on products as well as directing and monitoring students working on the product. Continue to phase $\mathrm{V}$ where in this phase students assist the industry/product ordering parties. The teacher checks the suitability of the product specifications made by students to go to the stage of assistance to the product ordering industry and facilitates and guides students for assistance to the industry regarding the products that have been made. Next phase VI finalizes the products made. The teacher explains to students the results of the assistance to the product ordering industry to further guide students to finalize the product based on the results of the assistance.

Phase VII is the teacher and students together to evaluate the final product work. The teacher directs students to make a final presentation of product work, facilitates student discussions about the final evaluation of the product manufacturing process, explains the results of the final evaluation of the product manufacturing process, and directs students to make a final product report. The last phase is the phase of product delivery to the ordering industry according to the product specifications requested.

\subsubsection{Results of Focus Group Discussion (FGD)}

The FGD activity was carried out after the IT-based ELIND learning model design process had been designed by the research team. Team of Experts with Research Teams involved in FGD activities in various fields of engineering expertise and research methodologies. The FGD implementation resulted in a revised model design which was then submitted for registration of IPR (Intellectual Property Rights). These results will be used in the model feasibility test at a later stage (Phase II). Some expert inputs are as follows.

The results of the FGD that had been carried out with 5 experts in the field of expertise provided several suggestions for improving the design of the IT-based ELIND learning model. IT Model syntax, 2) The initial phase/stage of the IT learning model syntax should be added to an initial phase, namely market needs analysis, 3) clarifying the link between the Industrial Electronics expertise program and the IT model, 3) an overview of the production process in the industry/a description of the production machines used with the application of PLC as the control, 4) Focus on the competencies to be achieved by students, not on the final product, 5) Add production process control technology to the table list of partner industry plans, 6) Several sensors and other automation systems can be added to miniature production machines to be made, considering the production process, 7) The 
evaluation instrument must be specific and standard to measure student competence.

\subsection{Discussion}

Productive teachers in the field of industrial electronics expertise have had sufficient experience supported by adequate contract teachers who have the knowledge and skills to work on some work equipment in the laboratory. The [12] states that a teacher must have adequate and competent skills in the field he is involved in, namely to improve his performance along with the achievements or results and outcomes of a job. Then, the [13] state that teacher quality is very important to support the country's economic development.

Competent teachers deliver students who can improve critical thinking skills and work skills. IT-based ELIND learning which has been designed with the stages of developing a learning model problem analysis, Teaching Industry Model Analysis (IT Model), and a description of the contents of the IT-based ELIND learning model, provides an IT model framework with systematic stages starting from analysis and development so that after being tested it is expected to be effective. develop critical thinking and work skills. Critical thinking skills are also related to students' ability to analyze arguments, make conclusions using reasoning, assess or evaluate, and make decisions or problem solving [9][11]. Critical thinking skills can be empowered through learning in schools, especially in vocational education as a provision for graduate competitiveness [14][15]. For this reason, optimizing learning critical thinking skills in the classroom is very important because it can affect student learning outcomes [16][17]. Critical thinking skills are a form of $21 \mathrm{st}-$ century skills that are expected to be able to equip students to have strong competitiveness in the face of job market competition [18][14]. Several key indicators in measuring critical thinking skills such as the ability to interpret, analyze, draw conclusions, evaluate, provide explanations, and self-regulation [15]. This explanation provides an understanding of the importance of integrating metacognitive strategies in learning tools. If the learning tools are packaged properly according to the learning objectives, they will grow HOTS abilities and produce effective learning.

Workability can be seen as a balance between work demands and individual resources. Workability is also defined as the extent to which the person can work [19]. Employability, defined as a balance between human resources and job demands, is an evidence-based concept [20]. Workability is a dynamic range of aspects, determination to build, and also individual characteristics that have been systematically and negatively correlated with age, and also systematically positively correlated with quality of work-life, quality of life, productivity, and general well-being [21]. Thus, students who have good work skills will make it easier to carry out their responsibilities in carrying out work at DUDI both during field Industrial practice and internships for a certain time.

Description of the contents of the ELIND learning model, containing the stages of learning with the following steps: (1) Analysis of market needs, (2) acceptance of orders, (3) Identification and analysis of order specifications, (4) Preparation of order processing planning documents (procedures)., timeline, product design, tools and materials, final specifications of the order), (5) Provision of tools and materials to be used, (6) Order processing process, (7) assistance to industry, (8) Finalization of workmanship, (9) Evaluation the end of the execution of the order, and (10) the submission of the order. This stage is by the miniature of industrial work process activities, the IT model that has been designed will provide a real picture of industrial processes for vocational students.

The next stage is to analyze the IT model by paying attention to the linked learning syntax, namely the PjBL and WBL approaches. The IT-based ELIND learning model with PjBL and WBL approaches where the syntax is product-based and produces students who can carry out the production process optimally. The implementation of the IT Model is ultimately able to improve critical thinking skills and work skills. The PjBL syntax consists of 4 stages, namely: 1) Reading about Science, (2) Direct Instruction, (3) Process Science Teaching, and (4) Project-based learning. WBL describes a school/university class program that brings together schools/universities and work organizations to create learning opportunities in the workplace [22][23][24].

The description of the results of the FGD on the design of the IT-based ELIND learning model was revised/improved then summarized in the following descriptions: 1) the IT model design provides clarity on the use of PjBL and work-based learning (WBL) syntax with the IT model syntax, 2) Initial phases / stages From the syntax of the IT learning model, an initial phase should be added, namely market needs analysis, 3) clarifying the link between the Industrial Electronics expertise program and the IT model, 3) describing the production process in the industry / description of the production machine used with the application of PLC as a control, 4) Focusing on competencies that students want to achieve, not in the final product, 5) Add production process control technology to the partner industry plan list table , 6) Several sensors and other automation systems can be added to the miniature production machine that will be made, and consider the production process, and 7) The evaluation instrument must be specific and standard to measure comm student potential. 
ELIND Learning Model-based IT to improve critical thinking skills and ability to work were developed consisting of five (5) components, namely: (1) Syntax: The syntax is a phase - the phase of activity in models of learning embodied in a series of learning activities. Thus, the syntax learning model designed in this research, in general, is the herb between design researchers with signs - signs or the classification of learning that has been put forward by the designers learning models such as: [25][26][27][28][29][30][31]; (2) Social system: Social system is a condition or situation or rule that applies in a learning model; (3) The principle of reaction: The principle of reaction is a pattern of activities that describe the teacher's response to students, both individually and in groups, as well as a whole; (4) Support system: The support system of a learning model is things that can support the achievement of learning objectives by applying a learning model [32]. The things referred to as a support system in the form of facilities, materials, devices, and aids or media; (5) Instructional impact and follower/accompaniment impact: The principle of model users must seek to synergize all model components to achieve learning objectives. Learning objectives are divided into main goals that are immediate/urgent to be achieved (instructional effect) and follower/accompaniment goals, namely goals that cannot be achieved immediately or the results cannot be obtained immediately after learning takes place, but are expected in a relatively long time (nurturant effect).

\section{CONCLusion}

Based on the results of data analysis and discussion of research results, it can be concluded that: (1) conduct a literature study, (2) Overview of teachers in vocational industrial electronics expertise in SMK can implement IT models, (3) Identify Industrial Electronics learning objectives tailored too with the IT model, (4) Analysis of Industrial Electronics learning problems developed with the IT Model approach, and (5) Analysis of the IT Model by bringing the concept of industrial processes closer to SMK, (6) Results of Focus Group Discussion (FGD), so that students can master optimally ELIND learning with industrial production processes and can develop critical thinking and work skills.

\section{ACKNOWLEDGMENTS}

For the completion of this research activity, the authors would like to thank:

1. Ministry of Education and Culture for granting DRPM funds for phase 1 multi-year research in 2021.

2. The Chancellor of the Makassar State University who has provided direction and motivation to the author
3. Chairman of the Institute for Research and Community Service who has facilitated this research activity.

4. Principal of SMK Negeri 2 and SMK Negeri 10 Makassar, for his permission and support in collecting data in this study.

\section{REFERENCES}

[1] S. Hadam, N. Rahayu, and A. N. Ariyadi, "Strategi Implementasi Revitalisasi SMK (10 Langkah Revitalisasi SMK)," Penerbit Direktorat Pembin. SMK Ditjen Pendidik. Vokasi, 2017.

[2] Sajidan, T. Martono, Suharno, P. Widyo, and F. D. Isnantyo, Konseptual Model Pengembangan Kompetensi Guru Produktif SMK Berbasis Industri. Jakarta: Direktorat Pembinaan Sekolah Menengah Kejuruan, 2017.

[3] S. Billett, Vocational Education Purposes, Traditions and Prospects. Springer Netherlands, 2011.

[4] Hendarman et al., Revitalisasi Pendidikan Vokasi, vol. 10, no. September. Kementerian Pendidikan dan Kebudayaan, 2016.

[5] Inpres, "Instruksi Presiden Nomor 9 Tahun 2016 tentang Revitalisasi SMK dalam rangka Peningkatan Kualitas dan Daya Saing SDM Indonesia." pp. 1-10, 2016, [Online]. Available: https://kemdikbud.go.id/main/files/download/e451 d9ec3a04121.

[6] M. Budiyanto, "Teaching Industry: Wahana Produksi Berbasis Riset \& Inovasi Untuk Mendukung Proses Pembelajaran Yang Teintegritas Dengan Industri,” 2015. https://sv.ugm.ac.id/2015/08/04/teaching-industrywahana-produksi-berbasis-riset-inovasi-untukmendukung-proses-pembelajaran-yang-teintegritasdengan-industri/.

[7] Y. I. Prastyawan, "Manajemen Pembelajaran Berbasis Industri," J. Manaj. dan Supervisi Pendidik., vol. 1, no. 2, pp. 176-180, 2017, doi: 10.17977/um025v1i22017p176.

[8] C. Sutianah, "Implementasi Model Pembelajaran Teaching Industry Berbasis Kewirausahaan Dan Motivasi Belajar Terhadap Peningkatan Kompetensi Keahlian Produktif Busana Butik dan Patiseri," Invotec, vol. 8, no. 1, pp. 30-45, 2012.

[9] K. Larsson, "Understanding and teaching critical thinking-A new approach,” Int. J. Educ. Res., vol. Volume 84, p. Pages 32-42, 2017, doi: https://doi.org/10.1016/j.ijer.2017.05.004. 
[10] S. Y. Seventika, Y. L. Sukestiyarno, and S. Mariani, "Critical thinking analysis based on Facione (2015) - Angelo (1995) logical mathematics material of vocational high school (VHS)," J. Phys. Conf. Ser., vol. 983, no. 1, 2018, doi: 10.1088/17426596/983/1/012067.

[11] J. E. McPeck, Critical thinking and education. Routledge Library Edition:Philosophy of Education, 2016.

[12] Nurfuadi, Manajemen Kompetensi Guru dalam Peningkatan Mutu Pembelajaran. Purwokerto: Penerbit STAIN Press, 2019.

[13] D. Nurhadi and N. M. Lyau, "Cultivating responsibilities of vocational teachers: a framework for preparing education to work," J. Pendidik. Teknol. dan Kejuru., vol. Vol 24, no. No 2, 2018.

[14] L. Bellaera, Y. Weinstein-Jones, S. Ilie, and S. T.Baker, "Critical Thinking in Practice: The Priorities and Practices of Instructors Teaching in Higher Education," Think. Ski. Creat., vol. Volume 41, 2021, doi: https://doi.org/10.1016/j.tsc.2021.100856.

[15] S. Cottrell, Critical thinking skills: Effective analysis, argument and reflection. Macmillan International Higher Education, 2017.

[16] R. Paul and L. Elder, The miniature guide to critical thinking concepts and tools. Dillon Beach : Rowman \& Littlefield Publishers, 2019.

[17] I. Sasson, I. Yehuda, and N. Malkinson, "Fostering the skills of critical thinking and question-posing in a project-based learning environment. Thinking Skills and Creativity, 29, 203-212.” 2018.

[18] M. A. A. Kadir, "What teacher knowledge matters in effectively developing critical thinkers in the 21 st century curriculum? Thinking Skills and Creativity, 23, 79-90." 2017.

[19] H. J. de Vries, M. F. Reneman, J. W. Groothoff, J. H. B. Geertzen, and S. Brouwer, "Self-reported work ability and work performance in workers with chronic nonspecific musculoskeletal pain," J Occup Rehabil, vol. 23, no. 1, pp. 1-10, 2013, doi: 10.1007/s10926-012-9373-1.

[20] J. Ilmarinen, M. Von, and Bonsdorf, "Work Ability," Encycl. Adulthood Aging, First Ed., pp. 187-206, 2015, doi: https://doi.org/10.1002/9781118521373.wbeaa254.

[21] C. Fernandes, A. Pereira, P. Bem-Haja, V. Amaral, and C. Silva, "Age and gender differences in work ability among industry worker: The foundation for safety intervention design," Saf. Sci., vol. 17, no. 1, 2013.

[22] D. Boud and N. Solomon, Work-based Learning: A New Higher Education? SRHE/OU Press, 2001.

[23] B. T. Siswanto, "Model penyelenggaraan workbased learning pada pendidikan vokasi Diploma III Otomotif," J. Pendidik. Vokasi, vol. 2, no. 1, pp. 1126, 2013, doi: 10.21831/jpv.v2i1.1013.

[24] T. Mahfud, "Evaluasi Program Praktik Kerja Lapangan Jurusan Tata Boga Politeknik Negeri Balikpapan," J. Pendidik. Teknol. dan Kejuru., vol. 23, no. 1, p. 110, 2016, doi: 10.21831/jptk.v23i1.9360.

[25] R. N. Evans, Foundations of Vocational Education. Charles E. Merril Pub. Co, 1971.

[26] J. B. Biggs, Teaching for Learning: The View from Cognitive Psychology. Australian Council for Educational Research, 1991.

[27] J. E. Kemp, G. R. Morrison, and S. M. Ross, Designing effective instruction. New York: Macmillan College Publishing Company., 1994.

[28] R. L. Lynch, Designing vocational and technical teacher education for the 21 st century: implications from the reform literature. Columbus: ERIC Clearinghouse on Adult, Career, and Vocational Education, Center on Education and Training for Employment, College of Education, Ohio State University, Columbus., 1997.

[29] R. I. Arends, Exploring teaching an introduction to education. Boston: McGraw-Hill, 2001.

[30] B. Joyce and M. Weil, Models of Teaching. New Delhi: Prentice-Hall of India, 2003.

[31] P. D. Eggen and D. P. Kauchak, Strategies for teachers: Teaching content and thinking skills. Prentice hall, 1988.

[32] A. S. Suparno, Membangun kompetensi belajar. Jakarta: Direktorat Jenderal Pendidikan Tinggi, 2000 . 